\title{
Natural Transformation of Zinc Oxide Nanoparticles and Their Cytotoxicity and Mutagenicity
}

\author{
Mei M. Wang, ${ }^{1,2}$ Juan Wang, ${ }^{3}$ Rui Cao, ${ }^{1}$ Si Y. Wang, ${ }^{1}$ and Hua Du ${ }^{3}$ \\ ${ }^{1}$ Department of Pathophysiology, Anhui Medical University, No. 81, Mei-Shan Road, Hefei, Anhui 230032, China \\ ${ }^{2}$ School of Public Health, Anhui Medical University, No. 81, Mei Shan Road, Hefei, Anhui 230032, China \\ ${ }^{3}$ Key Laboratory of Ion Beam Bioengineering, Hefei Institutes of Physical Science, Chinese Academy of Sciences and Anhui Province, \\ Hefei, Anhui 230031, China \\ Correspondence should be addressed to Si Y. Wang; sywang@ahmu.edu.cn and Hua Du; hua.du@ucr.edu
}

Received 2 May 2017; Revised 5 June 2017; Accepted 7 June 2017; Published 2 August 2017

Academic Editor: Kimberly Hamad-Schifferli

Copyright (C) 2017 Mei M. Wang et al. This is an open access article distributed under the Creative Commons Attribution License, which permits unrestricted use, distribution, and reproduction in any medium, provided the original work is properly cited.

With rapid development of the nanoindustry, studies focusing on the transformation of nanoparticles (NPs) are required to understand their stability and toxicity after being released into the environment. Here, we characterized the physicochemical properties of $\mathrm{ZnO} N$ Ps and found that they are naturally alkalized in the presence of air (without the addition of exogenous alkaline substances). Energy dispersive X-ray/X-ray powder diffraction/Fourier transform infrared (EDX/XRD/FTIR)/Raman spectroscopy gave evidence for the formation of hydrozincite $\left(\mathrm{Zn}_{5}\left(\mathrm{CO}_{3}\right)_{2}(\mathrm{OH})_{6}\right)$ and zinc hydroxide $\left(\mathrm{Zn}(\mathrm{OH})_{2}\right)$. Further, we comparatively evaluated the cellular toxicity of pristine and alkalized $\mathrm{ZnO}$ NPs. Cell viability testing (colony formation) showed that alkalization time-dependently decreased cytotoxicity. Alkalized NPs exhibited mutagenicity at multiple concentrations, as shown by a CD59 gene loci mutation assay. Variations in toxicity were associated with the chemical transformation of $\mathrm{ZnO} \mathrm{NPs}$, and $\mathrm{Zn}^{2+}$ played a key role in the mutagenicity of alkalized NPs. These results indicate that NPs are chemically transformed in the environment. These transformations result in obvious variations in toxicity, suggesting that the NP transformation process should be considered more thoroughly when evaluating toxicity.

\section{Introduction}

Nanoparticles (NPs) are important materials that primarily differ from their macroscopic counterparts in size and have been widely used in many different fields such as electronics, dyestuff, coating, medicine, clothing, and cosmetics [1-5]. As of October, 2013, the number of nanoproducts on the market reached 1628 according to emerging nanotechnology project statistics [6]. Consequently, NPs will inevitably contact environmental media (water, soil, sediment, etc.) directly or indirectly, with unpredictable impacts on ecosystems and human health [7-10]. Recently, issues have arisen regarding the types of NP transformations and stable products that may occur in the natural system and how they may, in turn, affect the nature, behavior, and adverse effects of NPs [10].

$\mathrm{ZnO}$ NPs are engineered nanomaterials that are commonly used in various human applications such as sunscreens, ceramics, rubber processing, wastewater treatment, and children's products $[11,12]$. It has been reported that a variety of environmental transformations, including aggregation [13], dissolution [14], sulfidation [15], and phosphorylation [16], are possible for ZnO NPs. For example, recent studies have shown that dissolution converts ZnO NPs into $\mathrm{Zn}^{2+}$ under suitable $\mathrm{pH}$ environments $[17,18]$. Also, newly formed products such as hydrozincite $\left(\mathrm{Zn}_{5}\left(\mathrm{CO}_{3}\right)_{2}(\mathrm{OH})_{6}\right)$, smithsonite $\left(\mathrm{ZnCO}_{3}\right)$, and zinc sulfide $(\mathrm{ZnS})$ are possible in the presence of an appropriate concentration of carbonate and sulfide and under suitable $\mathrm{pH}$ conditions [19-23]. An increasing number of studies have shown that $\mathrm{ZnO}$ NPs induce various toxic effects, including cytotoxicity, genotoxicity, inflammation, and oxidative stress [12, 24-28]. Among these documented adverse effects, mutagenicity is particularly important because it is inheritable and could therefore cause severe and far-reaching negative effects to human health [29]. Some studies have used the Ames test to show that $\mathrm{ZnO}$ NPs induce weak mutagenic potential in Salmonella 
typhimurium TA98, TA1537, and Escherichia coli WP2 trpuvrA $[19,25]$. However, most studies have reported that $\mathrm{ZnO}$ NPs are not mutagenic [30, 31]. These discrepancies may be attributable to the inability of prokaryotes to perform endocytosis; further, ZnO NPs may have antimicrobial properties [32], suggesting that bacteria are not a suitable model for studying their mutagenic potential. In addition, these studies only include analyses of pristine ZnO NPs; however, NPs likely undergo transformations after they are released into the environment, a phenomenon that has not been adequately considered. Several research groups have concluded that $\mathrm{ZnO}$ NP toxicity is primarily attributable to dissolved $\mathrm{Zn}^{2+}$ ions $[24,33]$. Others have shown that both nanoparticles and $\mathrm{Zn}^{2+}$ ions are likely to be major contributors [34-36]. While different, most of these toxicity studies focus only on pristine $\mathrm{ZnO}$ NPs rather than the transformed products expected in the environment, which likely have different properties from those of pristine NPs [35]. In addition, existing studies on NP transformations involve the addition of chemicals or adjustment of physical parameters; few studies have focused on natural transformation processes.

Here, we focus on possible natural transformations of $\mathrm{ZnO}$ NPs in ultrapure water without the addition of chemicals or other substances. The human-hamster hybrid $\left(A_{L}\right)$ cell line, formed by fusion of the gly2A mutant of Chinese hamster ovary $(\mathrm{CHO})$ cells with human fibroblasts, is sensitive to large deletion mutations [37] and was used in the present study to evaluate ZnO NP mutagenicity. We evaluated the relationship between naturally occurring transformations in ultrapure water and the consequential changes in $\mathrm{ZnO}$ NP toxicity. The NPs were carefully characterized, and cytotoxicity and mutagenicity of pristine and alkalized NPs were compared in $\mathrm{A}_{\mathrm{L}}$ cells. Further, we measured the release of $\mathrm{Zn}^{2+}$ and determined its role in NP toxicity. Possible physicochemical mechanisms underlying the observed changes in toxicity, as well as key factors influencing the natural transformation of $\mathrm{ZnO}$ NPs, were also studied and discussed.

\section{Materials and Methods}

2.1. Particles and Reagents. Commercial ZnO NPs (90$200 \mathrm{~nm}$ ) were purchased from NanoAmor (Houston, TX) with a purity of $99.9+\%$ and a specific surface area of $4.9-6.8 \mathrm{~m}^{2} / \mathrm{g}$. The particles were used as received. Biological reagents used in the experiments involving cell culture, including glycine, gentamicin, and Ham's F12 medium were of reagent grade and were purchased from Sigma-Aldrich (Shanghai, China). Crystal violet was purchased from Sangon Biotech (Shanghai, China). Model compounds, including $\mathrm{Zn}_{5}\left(\mathrm{CO}_{3}\right)_{2}(\mathrm{OH})_{6}$ and $\mathrm{Zn}(\mathrm{OH})_{2}$, were purchased from Quality Inspection Biotechnology (Beijing, China). Supplemental Ham's F12 medium was prepared by mixing $8 \%$ heatinactivated fetal bovine serum (Hyclone, Grand Island, NY), $2 \times 10^{-4} \mathrm{M}$ glycine, and $25 \mathrm{mg} / \mathrm{mL}$ gentamicin. All chemicals were used without further purification.

2.2. Natural Transformation of $\mathrm{ZnO} N P$ s. Pristine $\mathrm{ZnO}$ NPs were suspended in Milli-Q water (Millipore, $18 \mathrm{M} \Omega \mathrm{cm}$ ) at a concentration of $1 \mathrm{mg} / \mathrm{mL}$ and sterilized by heating to $120^{\circ} \mathrm{C}$ for 20 min. NP stock suspensions were sealed in brown glass reagent bottles.

For air-exposed NPs, suspensions were stored at $25^{\circ} \mathrm{C}$ and processed manually every 5 days as follows: samples were vortexed for $2 \mathrm{~min}$, sonicated at $30 \mathrm{~W}$ for $20 \mathrm{~min}$, and exposed to air on the sterile workbench for $5 \mathrm{~min}$ during the simulated transformation period (20,60, and 120 days). Unless otherwise stated, the transformation process was modeled per this procedure.

Control (pristine, no air exposure) NP suspensions were sealed and maintained in the dark at $25^{\circ} \mathrm{C}$ for the natural transformation period without any other manipulations before being applied to $A_{L}$ cells or physicochemical characterization.

\subsection{Physicochemical Characterization of Pristine and Trans-} formed NPs. Pristine and naturally transformed ZnO NPs were characterized with several techniques at $25^{\circ} \mathrm{C}$. Transmission electron microscopy (TEM, JEOL 2100 HT, Jeol, Japan) was used to determine NP size, shape, and morphology. The samples were prepared by dropping $10 \mu \mathrm{L}$ aliquots of the particle suspensions $(0.1 \mathrm{mg} / \mathrm{mL}$ in ultrapure water $)$ onto a copper grid and then air drying. A Zetasizer Nano Series S90 (Malvern Instruments) apparatus based on the dynamic light scattering (DLS) method was used to measure the hydrodynamic particle size of the NPs $(0.1 \mathrm{mg} / \mathrm{mL}$ suspensions). Analyses of transformation products resulting from exposure of $\mathrm{ZnO} \mathrm{NP}$ stock solutions $(10 \mu \mathrm{L}, 1 \mathrm{mg} / \mathrm{mL}$ in ultrapure water) to ultrapure water were conducted using FTIR and Raman spectroscopy. FTIR spectra of NPs (pristine or transformed) were collected between the spectral range of 400 and $4000 \mathrm{~cm}^{-1}$ using the $\mathrm{KBr}$ pellet technique. Raman spectra of NPs were obtained with a $532 \mathrm{~nm}$ laser and an Olympus 50x working distance lens using an Xplora Raman microspectrometer (Horiba Jobin Yvon). Chemical and structural characterizations of pristine or transformed $\mathrm{ZnO}$ NPs were measured by synchrotron-based X-ray diffraction (XRD, PANalytical B. V., Shanghai, China) and energy dispersive Xray spectrometry (EDX, JEOL 2100 HT, Jeol, Japan).

2.4. Cell Culture, Treatment, Morphology, and Viability. The comparative toxicity of pristine and transformed $\mathrm{ZnO}$ NPs was evaluated in the immortalized $A_{L}$ cell line derived from hybridization of hamster gly-A mutant $\mathrm{CHO}$ cells with normal human fibroblasts. The cell line contains a set of Chinese hamster $\mathrm{CHO}-\mathrm{K} 1$ chromosomes and a single copy of human chromosome 11. $\mathrm{A}_{\mathrm{L}}$ cells are sensitive to the cytotoxic effects of monoclonal E7.1 antibodies, which are specific to the CD59 antigen located on human chromosome 11 [38]. $A_{L}$ cells were cultured in supplemental Ham's F12 medium and seeded at a density of $1.5 \times 10^{5}$ cells per Petri dish (60-mm diameter) and incubated in a humidified incubator $\left(37^{\circ} \mathrm{C}, 5 \% \mathrm{CO}_{2}\right)$. The cells attached to the bottom of the dishes within $2 \mathrm{~h}$; after $24 \mathrm{~h}$, cells reached the exponential growth phase. ZnO NP stock solutions were vortexed for $2 \mathrm{~min}$ and sonicated $(30 \mathrm{~W}$ ) for $30 \mathrm{~min}$, and then aliquots were taken to prepare working solutions in supplemented Ham's F12 medium. In addition, the working solutions were sonicated at $30 \mathrm{~W}$ for $20 \mathrm{~s}$ and then dispersed into cell culture dishes to ensure proper 
dispersion of the NPs. Medium ( $4 \mathrm{~mL}$ ) containing pristine or transformed NP suspensions at various concentrations $(0,5$, $10,15,20,30,50$, and $60 \mu \mathrm{g} / \mathrm{mL}$ ) was immediately added to the test cells and supplemented medium $(4 \mathrm{~mL})$. Treated cells and control cells were cultured for $72 \mathrm{~h}$ at $37^{\circ} \mathrm{C}$. After treatment, the culture solution was removed and cell morphology was observed using a microscope (Nikon Eclipse Ti, Japan). For evaluation of cell viability, the control cells and treated cells were replated at a density of 300 cells per Petri dish $(60 \mathrm{~mm}$ diameter) in fresh supplemental medium and cultured for 8 days. The colonies were then fixed with formaldehyde, stained with crystal violet dye, and the number of surviving colonies was recorded. Survival fraction was defined as percentage of the plating efficiency of the treated group to the plating efficiency of the control group [38].

2.5. Mutation Potential. After treatment, cells were replated into $60 \mathrm{~mm}$ Petri dishes at $1 \times 10^{5}$ cells/dish and cultured for 7-14 consecutive days. This expression period allowed the cells to recover from the temporary growth lag after $\mathrm{ZnO}$ NP treatment and to multiply such that the progeny of the mutated cells no longer expressed lethal amounts of CD59 surface antigen. During this period, the medium was changed every second day and the cells were passaged once every 3-4 days. The cells were then harvested and $0.5 \times 10^{5}$ cells were seeded in $60 \mathrm{~mm}$ Petri dishes containing $2 \mathrm{~mL}$ supplemented Ham's F12 medium. After incubation in a $\mathrm{CO}_{2}$ incubator for $2 \mathrm{~h}$, freshly thawed antibodies $(0.2 \%)$ and complement $(1.5 \%(\mathrm{~V} / \mathrm{V}))$ were added. Each experiment consisted of the same batch for the control group, including the antibodyalone treatment group, the complement-alone treatment group, and the blank control group. Cultures were further incubated for 7 to 10 days until macroscopically visible clones were formed. The culture medium was then discarded and cells were fixed with formaldehyde and stained with crystal violet dye; the number of clones was then counted under white light. The mutation frequency (MF) was calculated as the number of surviving colonies divided by the total number of cells plated after correcting for any nonspecific cytotoxicity attributable to complement alone. The relative increase in mutation frequency is expressed as fold increase over background.

2.6. Quantification of $\mathrm{Zn}^{2+}$ and Its Contribution to Toxicity. $\mathrm{Zn}^{2+}$ released from pristine and alkalized $\mathrm{ZnO}$ NPs was quantified by inductively coupled plasma optical emission spectrometry (ICP-OES). Specifically, $50 \mu \mathrm{g} / \mathrm{mL}$ sonicated stock suspension was centrifuged in a Beckman Airfuge Ultracentrifuge at $20,000 \mathrm{rpm}$ for $30 \mathrm{~min}$ with cooling to precipitate solid particles. The supernatant was filtered through a Whatman alumina Anotop membrane $(0.02 \mu \mathrm{m}$ pore size, $47 \mathrm{~mm}$ diameter, Maidstone, Kent, UK), which excluded particles larger than $20 \mathrm{~nm}$. After high-speed centrifugation and membrane filtration, the concentration of elemental $\mathrm{Zn}$ $(206.200 \mathrm{~nm})$ in the supernatants was measured using ICPOES (Optima 7300 DV, Perkin Elmer Corporation, Norwalk, CT).

To determine the contribution of released $\mathrm{Zn}^{2+}$ to $\mathrm{ZnO}$ NP toxicity, we exposed $A_{L}$ cells to the supernatant of (nearly) lethal concentration (LC) 100 of NPs, as previously determined. NP suspensions without centrifugation and filtration were also applied to cells for comparison. Supplemented medium without $\mathrm{ZnO}$ NPs was added to the control cells. The detailed procedures for determining cell viability and for the mutation assay after treatment were the same as described above.

2.7. Effects of Air Exposure on Toxicity. After 60 days of storage in the dark at $25^{\circ} \mathrm{C}$, the transformed $\mathrm{ZnO} \mathrm{NP}$ suspensions (with air exposure) and control suspensions (without air exposure) were subjected to morphology analysis by TEM and cytotoxicity evaluation using the colony formation assay. The detailed procedures were the same as described above.

2.8. Data Analysis. All data in this study are represented as the means $\pm \mathrm{SD}$ of three to four replicates of identical experiments. Significant differences between treatments were determined by one-way analysis of variance (ANOVA). Results with $p<0.05$ were considered statistically significant.

\section{Results}

3.1. NP Properties. To analyze possible $\mathrm{ZnO}$ NP transformations in ultrapure water, morphological changes were observed with TEM. As shown in Figure 1(a), pristine $\mathrm{ZnO}$ NPs are a mixture of approximately spherical and rod-like particles. After alkalization for 20 days, a subtle change in the nanocrystal microstructures was observed. When the alkalization time was prolonged to 60 days, the number of visible NPs in one TEM caption sharply decreased and was replaced by sheets and a mesh material; NP morphology also began to significantly change. For example, the sharp crystal edges disappeared and were replaced by blurred and amphibolous boundaries, indicating corrosive damage on the NP surface. When $\mathrm{ZnO}$ NPs were alkalized in pure water for 120 days, the original NP morphology became less apparent, showing signs of dissolution during the alkalization process and becoming "flaky" and less solid in appearance. To further determine the transformation products, EDX was used to analyze ZnO NPs after undergoing alkalization for 20 and 120 days. As shown in Figure 1(a), zinc was the major constituent of the crystalline suspension after 20 days and the lamellar substances present after 120 days. To further determine the possible conversion products of $\mathrm{ZnO}$ NPs, we used FTIR and Raman spectroscopy, as well as XRD. FTIR and Raman data show the formation of $\mathrm{Zn}(\mathrm{OH})_{2}$ (characteristic peak at $1500 \mathrm{~cm}^{-1}$ in Figure 1(b) and characteristic peaks at $1153.7 \mathrm{~cm}^{-1}$ and $1508.9 \mathrm{~cm}^{-1}$ in Figure $\left.1(\mathrm{c})\right)$, which was then confirmed by XRD spectroscopy (card number 00-0030888). Further, XRD data show the neoformation of another $\mathrm{Zn}_{5}\left(\mathrm{CO}_{3}\right)_{2}(\mathrm{OH})_{6}$ solid phase (card number 00-011-0287) (Figure 1(d)). DLS, a method commonly used to characterize NPs, was used to determine the hydrodynamic size of the sonicated pristine and transformed NPs. Although this method is more accurate for assessing spherical than nonspherical NPs, it can provide the relative size and dispersion of nonspherical (irregular) NPs, including whether they are agglomerated. The results show a certain degree of NP aggregation in the 

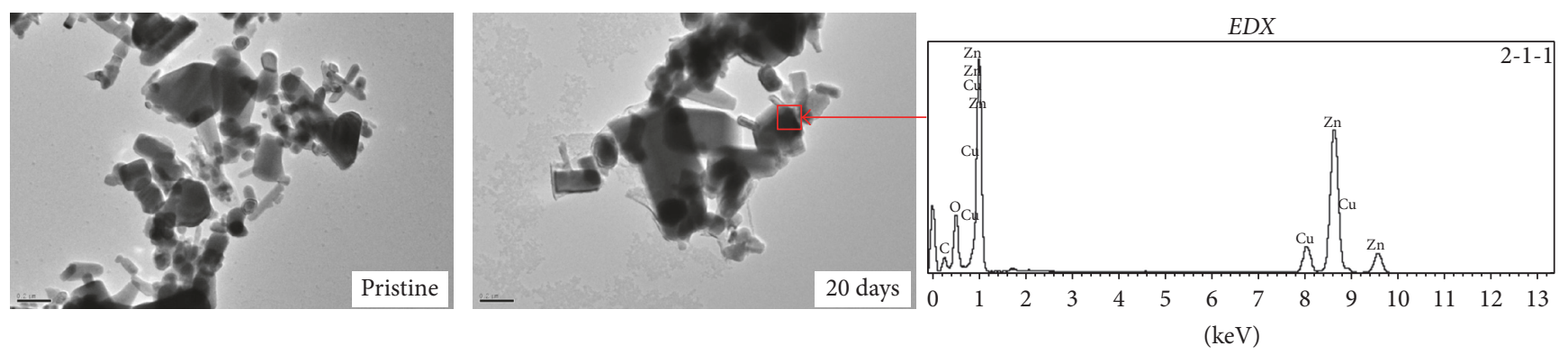

Full scale 4173 cts cursor: -0.085 (26cts)
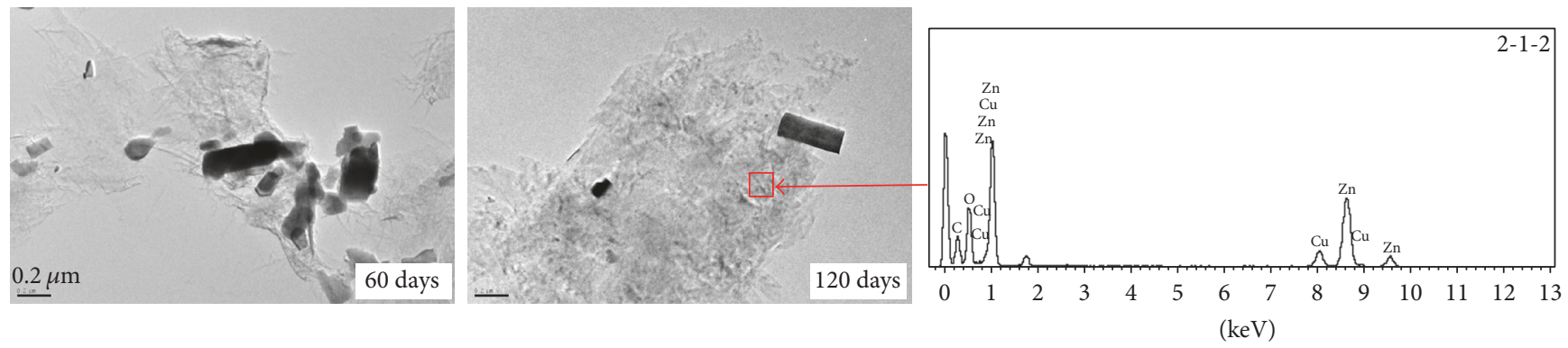

Full scale 1910 cts cursor: -0.347 ( 0 cts)

(a)
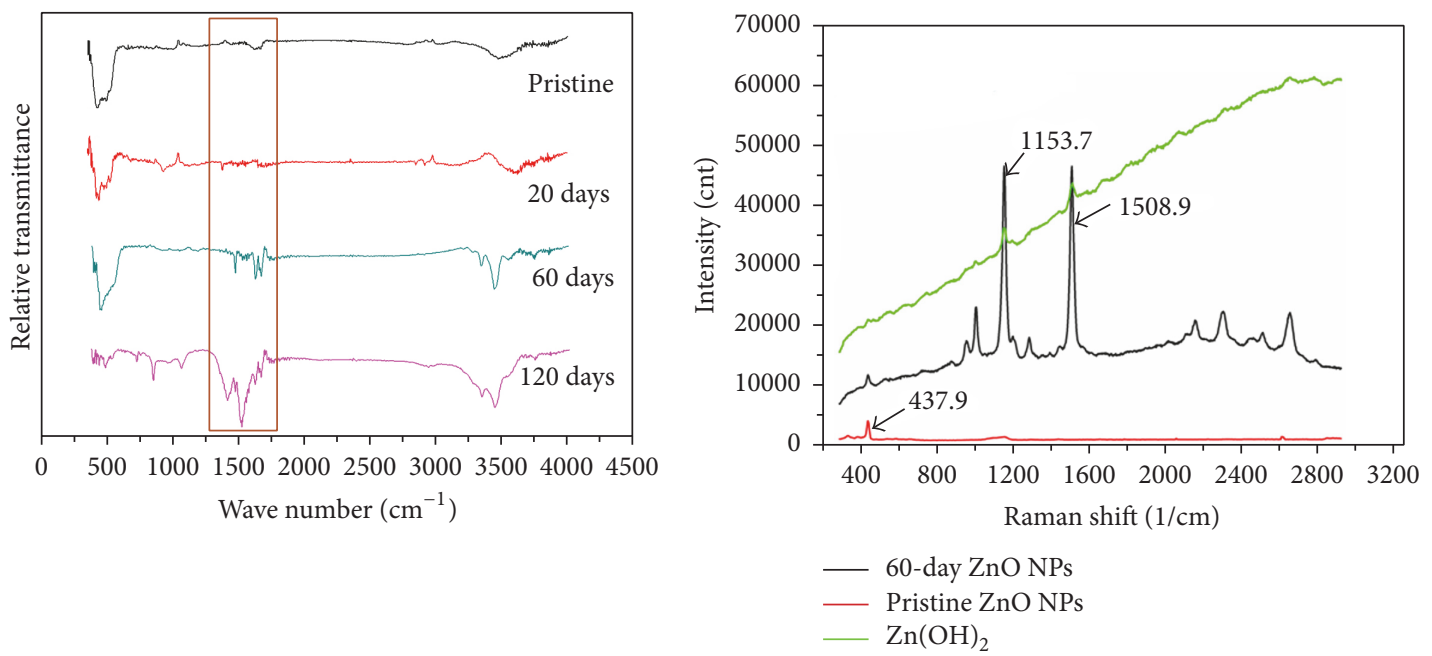

(c)

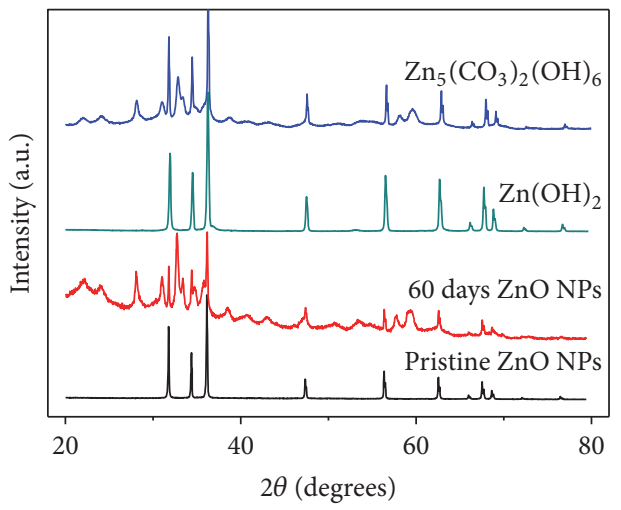

(d)

Figure 1: Characterization of pristine and naturally transformed $\mathrm{ZnO}$ nanoparticles (NPs). (a) Low resolution transmission electron microscopy (TEM) images of NPs and energy dispersive X-ray (EDX) measurements (indicated by the red squares) from ZnO NPs alkalized for 20 and 120 days. (b) Fourier transform infrared (FTIR) spectra of pristine and naturally transformed ZnO NPs. Orange squares indicate

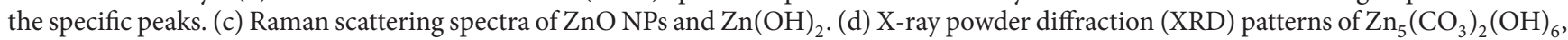
$\mathrm{Zn}(\mathrm{OH})_{2}$, pristine NPs, and NPs alkalized for 60 days. 
TABLE 1: Particle size and zinc concentration of pristine and alkalized NPs suspension.

\begin{tabular}{lccc}
\hline \multirow{2}{*}{ NPs with different alkalization time } & \multicolumn{2}{c}{ Hydrodynamic size $(\mathrm{nm})$} & Zn concentration in NP stock suspension $(\mu \mathrm{g} / \mathrm{mL})$ \\
\hline Pristine & $324.4 \pm 81$ & $117 \pm 33$ & 4.8970 \\
20 days & $394 \pm 141$ & $123 \pm 67$ & 9.1402 \\
60 days & $582 \pm 70$ & $157 \pm 116$ & 13.8040 \\
120 days & $633 \pm 97$ & $191 \pm 108$ & 28.1730 \\
\hline
\end{tabular}

Nanoparticle size was expressed as intensity-based average hydrodynamic diameter. Bars: \pm SD. The dissolved Zn concentration was measured by ICP-OES: $50 \mathrm{mg} / \mathrm{mL}$ NPs was suspended in Milli-Q water at $25^{\circ} \mathrm{C}$. After high-speed centrifugation (20,000 rpm for 30 min with cooling) and membrane filtration (Whatman alumina Anotop membrane, $0.02 \mu \mathrm{m}$ pore size, $47 \mathrm{~mm}$ diameter), the concentration of elemental $\mathrm{Zn}(206.200 \mathrm{~nm})$ in the supernatants was measured using ICP-OES.

stock suspensions ( $324.4 \pm 81 \mathrm{~nm}$ for pristine NPs and $633 \pm$ $97 \mathrm{~nm}$ for NPs after 120 days of alkalization) (Table 1), which is consistent with the TEM observations (Figure 1(a)). After dilution in supplemental Ham's F12 medium, the size of the $\mathrm{NP}$ agglomerates decreased obviously and there was a certain degree of difference between pristine $(117 \pm 33 \mathrm{~nm})$ and transformed $\mathrm{ZnO}$ NPs $(123 \pm 67 \mathrm{~nm}$ for NPs after 20 days, $157 \pm 116 \mathrm{~nm}$ for NPs after 60 days, and $191 \pm 108 \mathrm{~nm}$ for NPs after 120 days), as shown in Table 1 . These results are likely attributable to bovine serum albumin (BSA) and other components of the cell culture medium, which stabilize the NPs and contribute to their dispersion [39].

All these characterization results indicated that ZnO NPs were naturally alkalized (the process of making something alkaline without the addition of alkaline substances) in ultrapure water with air exposure.

3.2. Cytotoxicity. NP treatment results in a noticeable change in cellular shape, or morphology, in vitro [28]. Therefore, we examined cellular morphology by microscopy. As shown in Figure 2, cell morphology in the control group remained normal; the cells adhered well, with most attaching within $2 \mathrm{~h}$. Most cells were spindle-shaped or polygonal, with a few newly dividing cells showing a more transparent cytoplasm and better dispersion during the process of adhering. After treatment with $10 \mu \mathrm{g} / \mathrm{mL}$ pristine ZnO NPs for $72 \mathrm{~h}$, cell morphology significantly changed. Although most cells adhered within 3-5h, they could not spread, and some became rounded and lost the polygonal shape. When the concentration of $\mathrm{ZnO}$ NPs was increased to $15 \mu \mathrm{g} / \mathrm{mL}$, the treated cells atrophied and could not adhere, suggesting that cell viability was significantly lower than that of the control cells and cells treated with $10 \mu \mathrm{g} / \mathrm{mL}$. These results indicate that the $\mathrm{LC}_{100}$ for pristine $\mathrm{ZnO} \mathrm{NPs}$ is mostly like less than $15 \mu \mathrm{g} / \mathrm{mL}$. In contrast, cell morphology after treatment with $\mathrm{ZnO}$ NPs alkalized for 20 days $(10 \mu \mathrm{g} / \mathrm{mL})$ was not significantly different from that of the control group, and most of the cells could adhere and spread; however, no cells survived at a dose of $20 \mu \mathrm{g} / \mathrm{mL}$. A similar trend was observed in cells treated with $\mathrm{ZnO}$ NPs alkalized for 60 and 120 days; the $\mathrm{LC}_{100}$ in both treatment groups increased to approximately above 30 and $50 \mu \mathrm{g} / \mathrm{mL}$, respectively, with fewer dead cells observed after treatment with alkalized NPs, indicating that alkalized $\mathrm{ZnO}$ NPs are less cytotoxic than pristine $\mathrm{ZnO}$ NPs.
Viability assays are essential for evaluating the cellular response to toxicants. To measure total cell viability following NP exposure, we used a colony formation assay [40]. As shown in Figure 3, all ZnO NPs exhibited a dose-dependent increase in cytotoxicity regardless of the alkalization time. After treatment for $72 \mathrm{~h}$, significant toxicity was recorded at $10 \mu \mathrm{g} / \mathrm{mL}$ and higher $(p<0.05)$ in cells incubated with pristine and alkalized NPs, with a widely variable $\mathrm{LC}_{100}$ (pristine NPs: $15 \mu \mathrm{g} / \mathrm{mL}$; NPs alkalized for 20 days: $15.5 \mu \mathrm{g} / \mathrm{mL}$; NPs alkalized for 60 days: $32 \mu \mathrm{g} / \mathrm{mL}$; and NPs alkalized for 120 days: $60 \mu \mathrm{g} / \mathrm{mL}$ ). Notably, at concentrations between $10 \mu \mathrm{g} / \mathrm{mL}$ and the observed $\mathrm{LC}_{100}$, viability tended to be higher in cells treated with alkalized NPs than that of cells treated with pristine NPs (Figure 3). These results suggest that alkalized $\mathrm{ZnO}$ NPs cause less cytotoxicity than that of pristine ZnO NPs. Further, the decrease in cytotoxicity resulting from $\mathrm{ZnO} \mathrm{NP}$ exposure was dependent on the duration of alkalization.

3.3. Mutagenicity. We hypothesized that the lower toxicity observed in cells treated with alkalized $\mathrm{ZnO}$ NPs would translate to a safer product. To confirm this idea and to efficiently determine the mutagenic potential of $\mathrm{ZnO}$ NPs during the alkalization process, we conducted a CD59 gene loci mutation assay in $A_{L}$ cells. $A_{L}$ cells were plated at $80 \%$ confluency, with an average spontaneous mutation rate of $67 \pm 27$ mutant cells per $1 \times 10^{5}$ surviving cells. As shown in Figure 4, treatment with pristine $\mathrm{ZnO}$ NPs at $5 \mu \mathrm{g} / \mathrm{mL}$ and $10 \mu \mathrm{g} / \mathrm{mL}$ did not result in a significant increase in the mutation ratio. However, some cells that were adversely affected by treatment with pristine ZnO NPs $(15 \mu \mathrm{g} / \mathrm{mL})$ recovered from the temporary growth lag after culturing in fresh supplemental medium for 14 days (Figures 2 and 3); the mutation rate $(2.34 \pm 0.16, p<0.05)$ was significantly higher in these cells than that of the control group. A significant increase in mutation rate was observed in cells treated with NPs alkalized for 20 days at $5 \mu \mathrm{g} / \mathrm{mL}$ and above, with $1.89 \pm$ 0.24 being the highest measured maximum mutation rate. Further, a significant increase in mutation rate was shown in cells treated with NPs alkalized for 60 and 120 days at $\geq 10$ and $\geq 20 \mu \mathrm{g} / \mathrm{mL}$, with the highest maximum mutation rate measured as $1.63 \pm 0.15$ and $1.63 \pm 0.21$, respectively.

These results show that alkalized ZnO NPs have mutagenic capacity surpassing that of pristine NPs at certain concentrations. This is inconsistent with the previously 

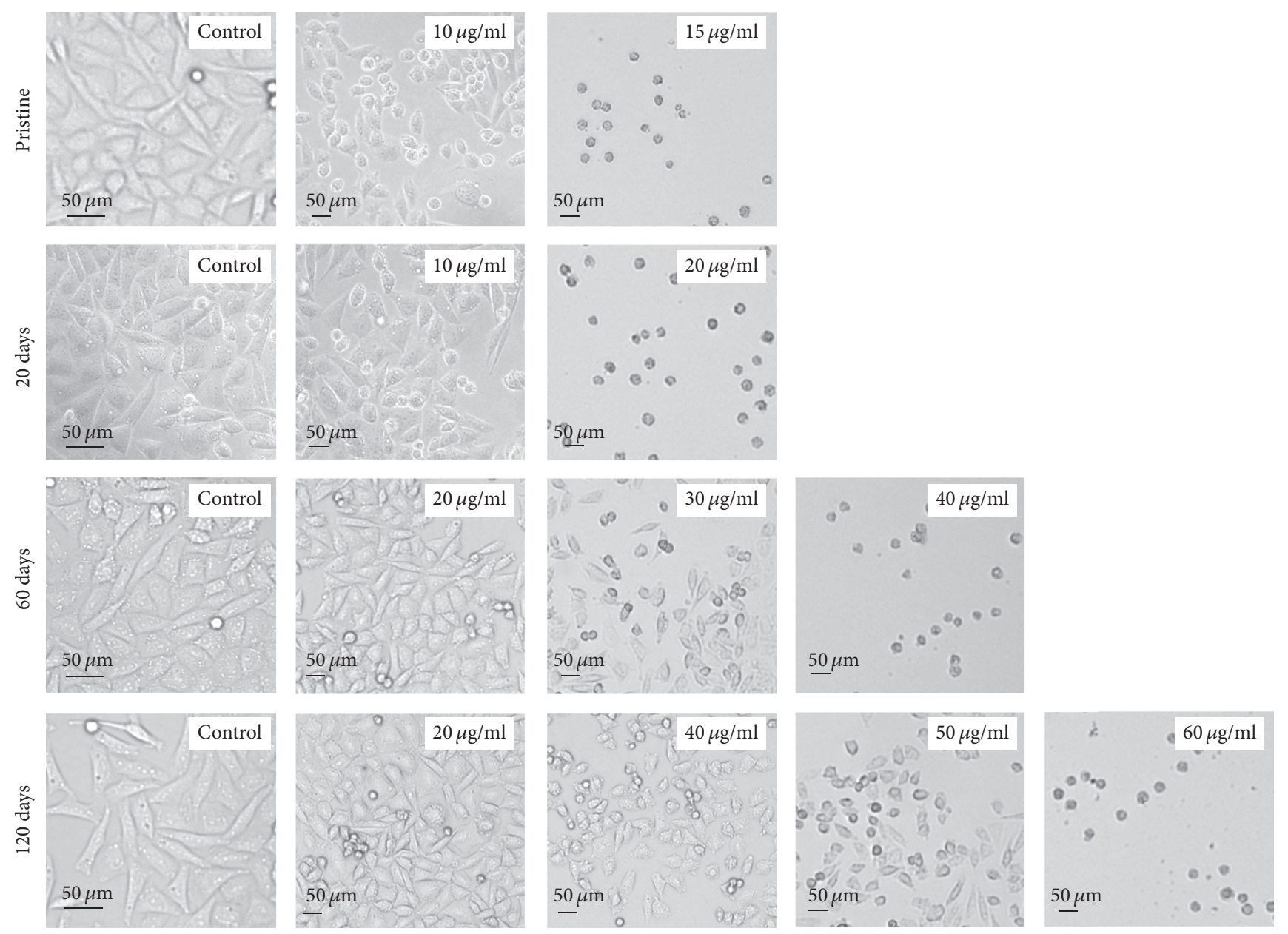

Figure 2: Morphology changes in $A_{L}$ cells after exposure to pristine or alkalized nanoparticles (NPs) for $72 \mathrm{~h}$ in supplemental Ham's F12 medium. $A_{L}$ cell morphology was observed with an optical microscope at 20x magnification for control groups and 10x magnification for NP-treated groups.

observed trend of lower ZnO NP cytotoxicity with increased transformation time and deserves further study.

3.4. Contribution of Released $\mathrm{Zn}^{2+}$ to the Toxicity of Pristine and Alkalized $\mathrm{ZnO} N P s$. To determine the role of $\mathrm{Zn}^{2+}$ in $\mathrm{ZnO} \mathrm{NP}$ toxicity during the natural alkalization process, we used a dose approaching the $\mathrm{LC}_{100}$ that still exhibited mutagenicity. After high-speed centrifugation and membrane filtration, $\mathrm{ZnO} \mathrm{NP}$ supernatants were dispersed in Milli-Q water at a concentration of $50 \mathrm{mg} / \mathrm{mL}$; ICP-OES was used to determine the amount of $\mathrm{Zn}^{2+}$ released from the NPs during the alkalization process. As shown in Table 1, the concentration of dissolved $\mathrm{Zn}^{2+}$ in the $\mathrm{ZnO}$ NP suspensions increased with the alkalization time, and the maximum concentration of $\mathrm{Zn}^{2+}$ after 120 days was $28.17 \mu \mathrm{g} / \mathrm{mL}$. Our results show that $\mathrm{ZnO} \mathrm{NP}$ dissolution is slightly enhanced by alkalization, accompanied by transformation of the crystalline phase. After quantitative determination of the dissolved $\mathrm{Zn}^{2+}$ concentration, $\mathrm{A}_{\mathrm{L}}$ cells were treated with the $\mathrm{ZnO} \mathrm{NP}$ supernatants. As shown in Figure 5(a), the viability of cells treated with the supernatants of pristine NPs $(15 \mu \mathrm{g} / \mathrm{mL})$,
NPs alkalized for 20 days $(15 \mu \mathrm{g} / \mathrm{mL})$, NPs alkalized for 60 days $(30 \mu \mathrm{g} / \mathrm{mL})$, and NPs alkalized for 120 days $(60 \mu \mathrm{g} / \mathrm{mL})$ remained at $95.16 \pm 4.11 \%, 77.79 \pm 1.78 \%, 75.63 \pm 3.26 \%$, and $64.44 \pm 1.78 \%$, respectively. Although there was alkalization time-dependent increase in cytotoxicity attributable to treatment with the $\mathrm{ZnO} \mathrm{NP}$ supernatant, cell viability remained above $60 \%$. These results indicate that $\mathrm{Zn}^{2+}$ did not contribute significantly to the cytotoxic effects of $\mathrm{ZnO}$ NPs. In contrast, the mutagenicity of pristine and alkalized $\mathrm{ZnO}$ NPs was more dependent on the concentration of $\mathrm{Zn}^{2+}$ in the $\mathrm{ZnO} \mathrm{NP}$ supernatant. Specifically, the mutation rate in cells treated with supernatant from pristine NPs was $1.21 \pm 0.22$, which was approximately half of that observed with the $\mathrm{ZnO} \mathrm{NP}$ suspension $(2.32 \pm 0.21)(p<0.05)$ (Figure 5(b)), indicating that the mutagenicity of pristine NPs is attributable to both the particles and $\mathrm{Zn}^{2+}$ released into the supernatant. When the transformation time was extended to 20 days, the $\mathrm{Zn}^{2+}$ released into the supernatant played a more significant role in the mutagenic effects of the $\mathrm{ZnO}$ NPs. The mutagenic frequency of $\mathrm{Zn}^{2+}$ released into the supernatant from $\mathrm{ZnO}$ NPs alkalized for 60 and 120 days was $1.27 \pm 0.21$ and $1.54 \pm$ 


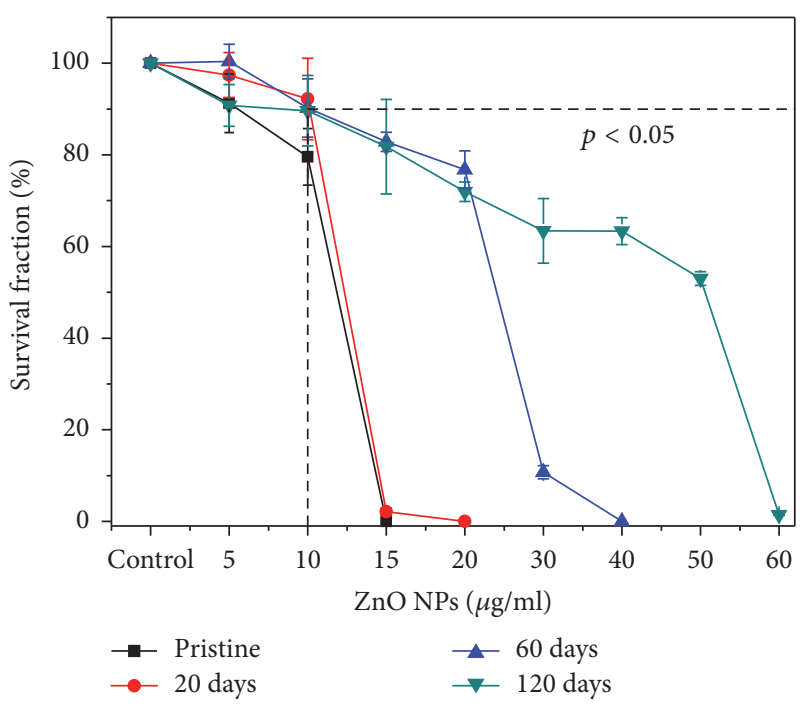

FIgURE 3: Survival fractions of $A_{L}$ cells after pristine or alkalized nanoparticle (NP) exposure. Naturally alkalized $\mathrm{ZnO}$ nanoparticles (NPs) induced lower cytotoxicity than that of pristine NPs in $A_{L}$ cells grown in supplemental Ham's F12 medium. Results are expressed as the percent of cell activity compared to the control using different $\mathrm{NP}$ concentrations for $72 \mathrm{~h}$. The data are presented as the means \pm $\mathrm{SD}$ of at least three independent experiments. The values represented by a dashed line are significant $(p<0.05)$ when compared to the survival fraction of the control group.

0.22 , respectively, which is similar to the values measured for alkalized $\mathrm{ZnO} \mathrm{NP}$ suspensions $(1.48 \pm 0.06$ and $1.42 \pm$ 0.01 ) (Figure 5(b)). These data indicate that $\mathrm{Zn}^{2+}$ is solely responsible for the mutagenic potential of $\mathrm{ZnO}$ NPs alkalized for 120 days (Figure 5(b)).

\subsection{High-Frequency Exposure to Air Led to a More Intense} Transformation and Variations in ZnO NP Toxicity. The above results were based on pristine NPs as well as airexposed alkalized NPs. To determine the key factors influencing the alkalization transformation process, we observed changes in toxicity and cell morphology in $A_{L}$ cells after treatment with $\mathrm{ZnO}$ NPs undergoing the alkalization process for 60 days in the absence of air. As shown in Figure 6, we observed dramatic differences in cells treated with airexposed alkalized ZnO NPs; however, there were no obvious changes in morphology between cells treated with pristine NPs and those that underwent the alkalization process in the absence of air (Figures 6(a) and 6(c)). For cells exposed to $\mathrm{ZnO}$ NPs alkalized for 60 days in the absence of air, phenotype (Figures 6(d) and 6(f)) and cell viability (Figures $6(\mathrm{~g})$ and $6(\mathrm{i})$ ) were almost the same as those of pristine $\mathrm{ZnO} \mathrm{NPs}$ at the same dose. These results illustrate that, in the absence of air, ZnO NPs are less likely to undergo alkalization. Subsequently, few changes were observed for ZnO NP cytotoxicity.

\section{Discussion}

Nanoparticles are highly reactive and dynamic in natural systems, and it is important to understand how the properties

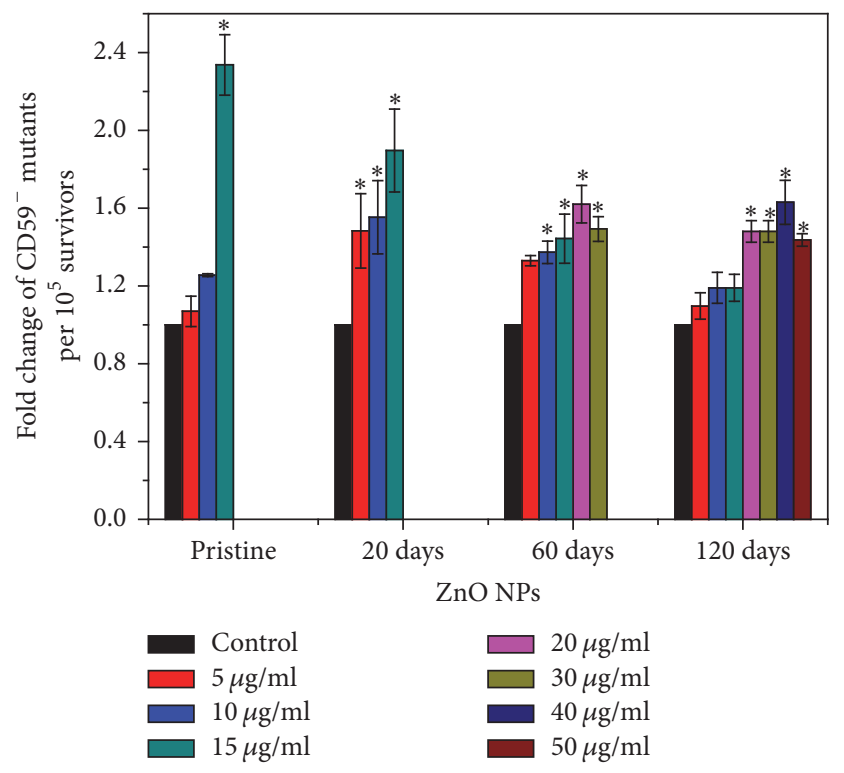

FIGURE 4: Mutation frequencies in $\mathrm{A}_{\mathrm{L}}$ cells after pristine or alkalized nanoparticle (NP) exposure. The relative ratio of increased mutation frequencies is expressed as a fold increase over the background after treatment with different NP concentrations for $72 \mathrm{~h}$. The data are presented as means \pm SD of at least three independent experiments. Significance is indicated by ${ }^{*} p<0.05$.

of transformed NPs affect their fate, transport, and toxicity [10]. Studies have shown that NPs undergo a series of chemical conversions, including chemical adsorption of toxic metal anions, complexation of organic molecules, and subsequent dissolution [41-43]. In addition, NP aging (weathering) affects dissolution and reactivity [13, 44, 45]. Previously, we reported that $\mathrm{ZnO}$ NPs undergo a dramatic physicochemical transformation with aging [22]. Here, we confirm a similar transformation process and the neoformation of $\mathrm{Zn}_{5}\left(\mathrm{CO}_{3}\right)_{2}(\mathrm{OH})_{6}$ (Figure 1). Further, we clarify that the transformation is a natural alkalization (without exogenous alkaline substances added) process. We suggest that the alkalization is attributable to the exposure of suspended $\mathrm{ZnO}$ NPs to air rather than just storage in ultrapure water.

Studies have reported similar transformations of $\mathrm{ZnO}$ NPs to $\mathrm{ZnCO}_{3}$ and $\mathrm{Zn}_{5}\left(\mathrm{CO}_{3}\right)_{2}(\mathrm{OH})_{6}$; however, there is little data regarding the corresponding toxicity [19-21]. Furthermore, the presence of additional chemicals, such as sulfides and phosphates, may result in additional chemical reactions and facilitate NP transformation $[15,16]$. There has been little research on the natural transformation process of NPs; Zhang et al. (2016) [23] recently analyzed the physicochemical transformation of $\mathrm{ZnO}$ NPs during the aging process as well as toxicity in green algae, in which natural NP transformations were observed at room temperature over time (0-210 days); however, the authors did not mention details of how the aging process was modeled. In our present work, we confirmed the chemical transformation (natural alkalization) of $\mathrm{ZnO}$ NPs into $\mathrm{Zn}_{5}\left(\mathrm{CO}_{3}\right)_{2}(\mathrm{OH})_{6}, \mathrm{Zn}(\mathrm{OH})_{2}$, and $\mathrm{Zn}^{2+}$ (Figure 1), as well as changes in the chemical properties that could result in variations in $\mathrm{ZnO} \mathrm{NP}$ cytotoxicity and mutagenicity, especially 


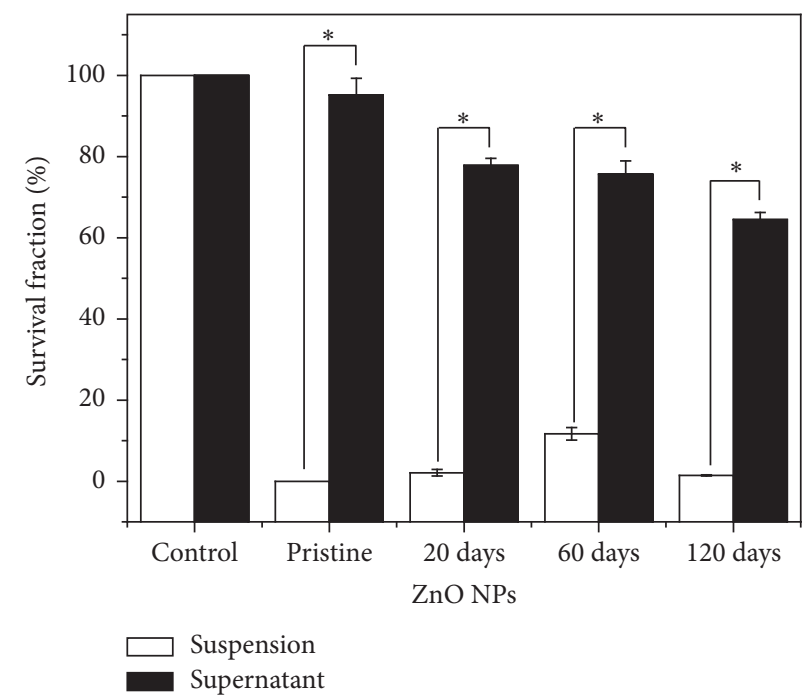

(a)

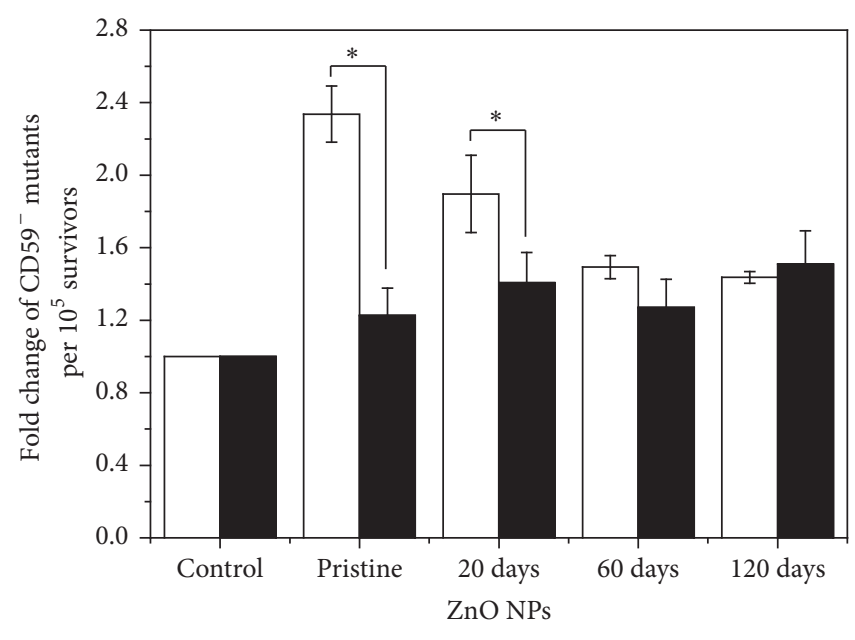

Suspension Supernatant

Figure 5: The contribution of $\mathrm{Zn}^{2+}$ in the supernatant fraction to cell survival. (a) The mutation potential of pristine and alkalized $\mathrm{ZnO}$ nanoparticles (NPs) at a concentration approaching the lethal concentration (LC ${ }_{100}$, pristine NPs: $15 \mu \mathrm{g} / \mathrm{mL}$; NPs alkalized for 20 days: $15 \mu \mathrm{g} / \mathrm{mL}$; NPs alkalized for 60 days: $30 \mu \mathrm{g} / \mathrm{mL}$; and NPs alkalized for 120 day: $60 \mu \mathrm{g} / \mathrm{mL}$ ) for $72 \mathrm{~h}$ is shown. (b) After high-speed centrifugation and membrane filtration, $A_{L}$ cells were treated with the NP supernatants at concentrations approaching the $\mathrm{LC}_{100}$ for $72 \mathrm{~h}$. The NP suspension without centrifugation was used as a control. Bars: \pm SD. $*$ indicates $p<0.05$.

the mutagenic potential of $\mathrm{ZnO}$ NPs given at the $\mathrm{LC}_{100}$. $\mathrm{ZnO}$ NP aggregation occurring during the alkalization process, and the hydrodynamic particle size of the NPs in water suspensions increased from $324.4 \pm 81 \mathrm{~nm}$ (pristine) to $633 \pm$ $97 \mathrm{~nm}$ (NPs alkalized for 120 days) (Table 1). After dilution in cell culture medium, the extent of aggregation declined obviously. We also observed that, with the extension of alkalization time, the degree of NP agglomeration increased, while their cytotoxicity gradually weakened (Figures 2 and 3 ), which could partly explain the difference in toxicity observed between pristine and alkalized ZnO NPs. Furthermore, we found that high-frequency exposure to air is necessary for variations in $\mathrm{ZnO} \mathrm{NP}$ alkalization and toxicity to occur (Figure 6). This is likely attributable to the conversion of $\mathrm{ZnO}$ NPs into $\mathrm{Zn}_{5}\left(\mathrm{CO}_{3}\right)_{2}(\mathrm{OH})_{6}$, which requires the participation of $\mathrm{CO}_{2}$.

Unlike cytotoxicity, which is a lethal effect of toxic substances, genotoxicity reflects the mutagenic effects of toxic and exogenous substances to DNA and RNA, as well as deleterious genetic changes in offspring. Mutations to DNA, which are associated with cancer, may occur if the damage is not repaired in time [46]; therefore, determining the mutagenicity of $\mathrm{ZnO} N P$ s is important. Previously, we found that aged ZnO NPs have significant protuberance $(p<0.05)$, which agrees with $\mathrm{ZnO} N P$ research in bacteria $[19,25]$. Based on the results of the CD59 gene loci mutation assay in $A_{L}$ cells, we determined that dying or severely damaged cells were able to recover from the temporary growth lag after $\mathrm{ZnO}$ NPs treatment; therefore, we focused on the mutagenicity of (nearly) lethal doses of $\mathrm{ZnO}$ NPs. After treatment with $\mathrm{ZnO}$ NPs at a dose approaching the $\mathrm{LC}_{100}$, some cells near death were able to recover from the temporary growth lag and exhibited a higher frequency of mutations than that of surviving cells treated with a lower dose (Figure 4). In other words, transformed $\mathrm{ZnO}$ NPs with low cytotoxicity caused genetic damage and mutations in surviving cells. These results suggest that the adverse effects attributable to transformed NPs could be more serious than those of pristine NPs. Therefore, it is very important to select more effective and appropriate detection systems and methods for evaluating NP safety.

Dissolution is an important process that affects surface properties, toxicity, and NP persistence. This is particularly true for NPs made from Group B soft metal cations, such as $\mathrm{Ag}, \mathrm{Zn}$, and $\mathrm{Cu}[10]$. The role of dissolution and undissolved particles in $\mathrm{ZnO} \mathrm{NP}$ toxicity has been studied in vitro and in vivo $[26,47,48]$. However, no consistent conclusions have been reached concerning the primary contributor to $\mathrm{ZnO}$ $\mathrm{NP}$ toxicity. It is well accepted that $\mathrm{ZnO}$ NPs dissolve and release $\mathrm{Zn}^{2+}$ ions, which reduces persistence but increases toxicity [10]. Song et al. [24] reported that dissolved $\mathrm{Zn}^{2+}$ is the primary contributor to cell death in mouse macrophage Ana-1 cells. In contrast, microbial growth is inhibited by $\mathrm{ZnO}$ NP suspensions rather than suspension supernatants, indicating that the toxic effects are primarily attributable to $\mathrm{ZnO}$ NPs rather than dissolved $\mathrm{Zn}^{2+}$ [34]. These conflicting observations may be attributable to the origin of $\mathrm{ZnO}$ NPs transformed in the aqueous environment, stability of the stock suspensions, exposure method, and/or the nature of the experimental models. A fundamental understanding of the scope and extent of the contribution from both dissolved and undissolved particulates to NP toxicity can provide essential information regarding the potential risks to ecosystems 


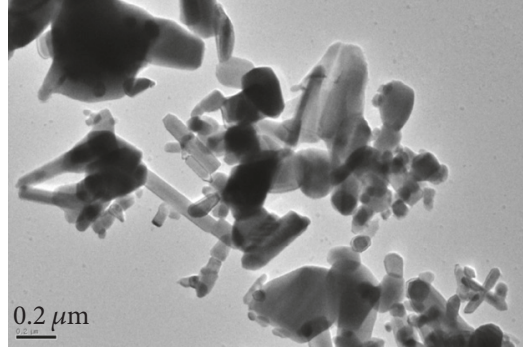

(a)

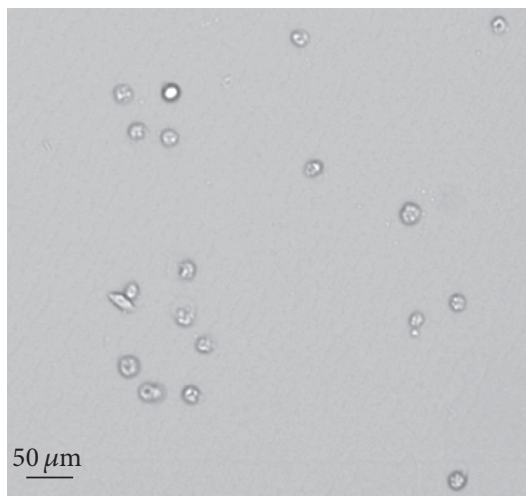

(d)

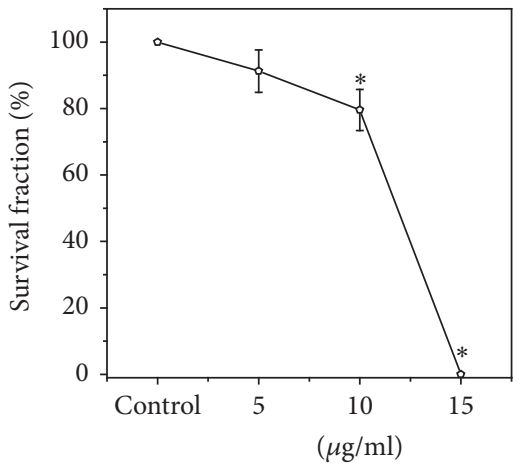

$\multimap$ Pristine NPs

(g)

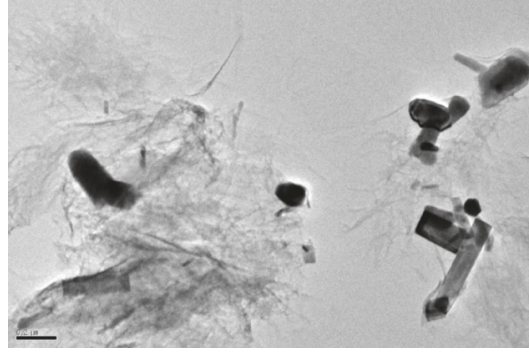

(b)

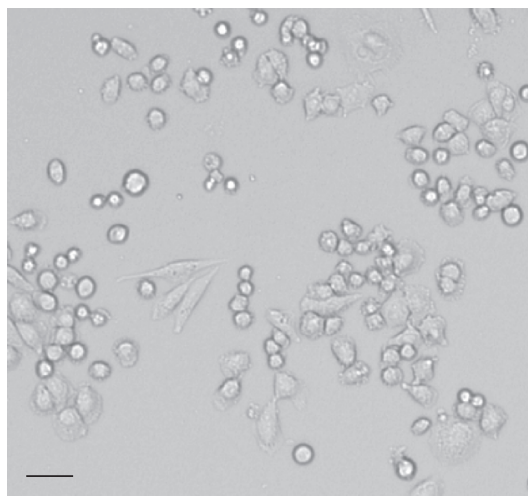

(e)

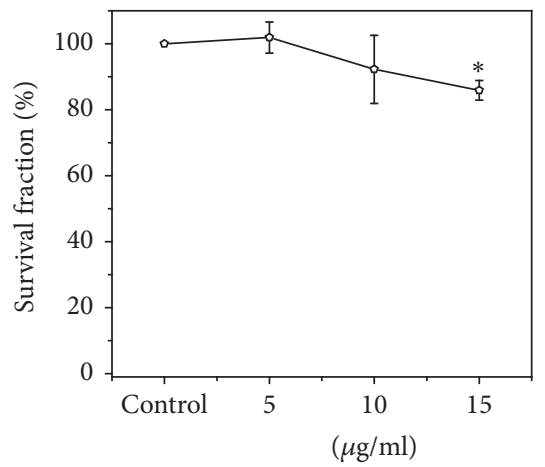

- -60 -day NPs with air exposure

(h)

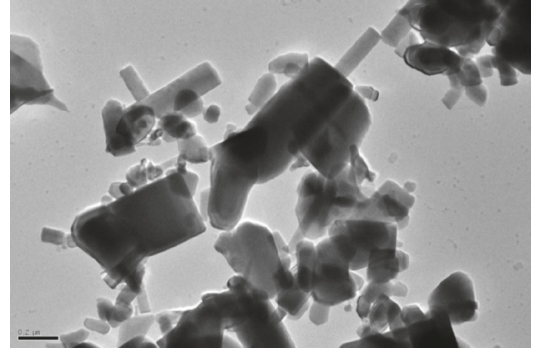

(c)

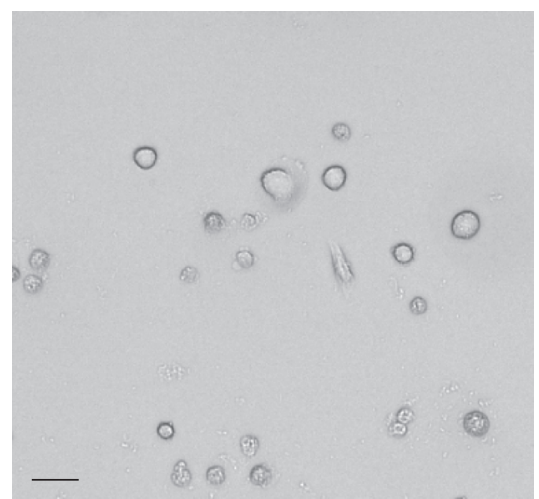

(f)

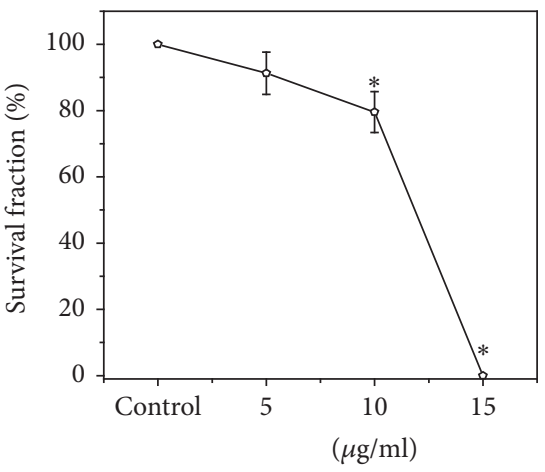

$\multimap$ 60-day NPs without air exposure

(i)

FIGURE 6: Morphology changes and variations in the survival fraction of $A_{L}$ cells treated with ZnO NPs with high/low-frequency exposure to air. Low resolution transmission electron microscopy (TEM) images of (a) pristine NPs, (b) NPs alkalized for 60 days with air exposure, and (c) NPs alkalized for 60 days without air exposure. Images of $A_{L}$ cells treated with (d) pristine, (e) NPs alkalized for 60 days with air exposure, and (f) NPs alkalized for 60 days without air exposure at $15 \mu \mathrm{g} / \mathrm{mL}$ for $72 \mathrm{~h}$. Survival fractions of $A_{L}$ cells treated with (g) pristine, (h) NPs alkalized for 60 days with air exposure, and (i) NPs alkalized for 60 days without air exposure for $72 \mathrm{~h}$. The data are presented as means \pm SD of at least three independent experiments. Significance is indicated by ${ }^{*} p<0.05$.

and humans. In the present study, the role that dissolved $\mathrm{Zn}^{2+}$ in $\mathrm{ZnO} \mathrm{NP}$ supernatant plays in overall toxicity was investigated. We focused on the toxicity of alkalized $\mathrm{ZnO}$ $\mathrm{NP}$ concentrations approaching the $\mathrm{LC}_{100}$. As shown in Figure 5(a), the presence of $\mathrm{Zn}^{2+}$ could not fully explain viability of $A_{L}$ cells exposed to a dose of alkalized $\mathrm{ZnO}$ NPs approaching the $\mathrm{LC}_{100}$. However, mutation frequencies induced by alkalized $\mathrm{ZnO}$ NPs, especially those alkalized for 120 days, could stem from the primary contribution of $\mathrm{Zn}^{2+}$ (Figure 5(b)). We could not determine whether $\mathrm{Zn}^{2+}$ is a major contributor to toxicity from these results. Although numerous studies have discussed the role of $\mathrm{Zn}^{2+}$ ions in ZnO NP toxicity $[24,34,49]$, there are no relevant studies regarding the positive mutagenicity results. It is possible that the mechanisms underlying $\mathrm{ZnO} \mathrm{NP}$ cytotoxicity differ from those underlying ZnO NP mutagenicity. Previously, we revealed that, during the aging process, $\mathrm{Zn}^{2+}$ ions and solid particles contribute differently to the mutagenicity of $\mathrm{ZnO}$ NPs [22]. These observations indicate that the mechanisms of $\mathrm{ZnO} \mathrm{NP}$ toxicity are complicated and more studies focusing 
on mutagenicity and NP transformations in the environment are needed.

In addition, it should be noted that this study only examined the transformed products using several fundamental and routine qualitative methods (TEM, DLS, FTIR/Raman, and XRD spectroscopy). The use of more accurate and sophisticated quantitative methods (e.g., extended X-ray absorption fine structure (EXAFS) spectroscopy) could be helpful to assess the alkalization process of $\mathrm{ZnO}$ NPs in an aqueous environment. In addition, we concentrated only on the most obvious factor (exposure to air) influencing the alkalization process by comparing air-exposed NPs to those without air exposure. Despite being preliminary in nature, this study clearly indicates the complexity of the NP transformation process in the environment. Further, more consideration should be given to the assessment of transformed NP toxicity.

\section{Conclusions}

In the present study, the natural alkalization of $\mathrm{ZnO}$ NPs in ultrapure water was confirmed, and variations in toxicity with extended alkalization time were investigated. The neoformed solid $\mathrm{Zn}_{5}\left(\mathrm{CO}_{3}\right)_{2}(\mathrm{OH})_{6}$ and $\mathrm{Zn}(\mathrm{OH})_{2}$, accompanied by the release of $\mathrm{Zn}^{2+}$, were confirmed by a series of characterization methods. Alkalized ZnO NPs induced lower cytotoxicity while relatively high degree mutation frequency than pristine $\mathrm{ZnO}$ NPs, implying that the chemical transformation of $\mathrm{ZnO}$ NPs could directly alter their toxicity together with the physical transformation (aggregation). Our work also shows the important role of $\mathrm{Zn}^{2+}$ in the mutation potential of alkalized NPs. Moreover, we found that air exposure is a key factor influencing the alkalization process, along with alkalization time. Our work suggests that the natural transformation of NPs occurs in the absence of extra chemicals. Further, detailed modeling of the natural transformation process should be considered when evaluating NP toxicity in the laboratory. Alkalization and many other transformation processes in aquatic environments may have a more substantial effect on the behavior of NPs and their toxic effects.

\section{Conflicts of Interest}

The authors have no conflicts of interest to declare.

\section{Authors' Contributions}

Dr. Meimei Wang and Hua Du designed the study. Dr. Meimei Wang conducted most of the experimental work and analyzed the data with important help from Dr. Siying Wang, Ms. Juan Wang, and Ms. Rui Cao. Dr. Meimei Wang and Hua Du wrote the article, and all authors approved the final manuscript.

\section{Acknowledgments}

This work was financially supported by grants from National Natural Sciences Foundation of China (21507002), by grants from China Postdoctoral Science Foundation
(2015M82023 and 2016M600477), by Scientific Research of BSKY (XJ201506) from Anhui Medical University, and by CPSF-CAS Joint Foundation for Excellent Postdoctoral Fellows (2015LH0017).

\section{References}

[1] N. Feliu and B. Fadeel, "Nanotoxicology: no small matter," Nanoscale, vol. 2, no. 12, pp. 2514-2520, 2010.

[2] J. Lee, S. Mahendra, and P. J. J. Alvarez, "Nanomaterials in the construction industry: a review of their applications and environmental health and safety considerations," ACS Nano, vol. 4, no. 7, pp. 3580-3590, 2010.

[3] M. C. Roco, "The long view of nanotechnology development: the national nanotechnology initiative at 10 years," Journal of Nanoparticle Research, vol. 13, no. 3, p. 1335, 2011.

[4] V. Kumar, A. Kumari, P. Guleria, and S. K. Yadav, "Evaluating the toxicity of selected types of nanochemicals," Reviews of Environmental Contamination and Toxicology, vol. 215, pp. 39121, 2012.

[5] D. E. Lefebvre, K. Venema, L. Gombau et al., "Utility of models of the gastrointestinal tract for assessment of the digestion and absorption of engineered nanomaterials released from food matrices," Nanotoxicology, vol. 9, no. 4, pp. 523-542, 2015.

[6] M. E. Vance, T. Kuiken, E. P. Vejerano et al., "Nanotechnology in the real world: redeveloping the nanomaterial consumer products inventory," Beilstein Journal of Nanotechnology, vol. 6, no. 1, pp. 1769-1780, 2015.

[7] V. L. Colvin, "The potential environmental impact of engineered nanomaterials," Nature Biotechnology, vol. 21, no. 10, pp. 1166-1170, 2003.

[8] D. B. Warheit, C. M. Sayes, K. L. Reed, and K. A. Swain, "Health effects related to nanoparticle exposures: environmental, health and safety considerations for assessing hazards and risks," Pharmacology and Therapeutics, vol. 120, no. 1, pp. 35-42, 2008.

[9] A. R. Petosa, D. P. Jaisi, I. R. Quevedo, M. Elimelech, and N. Tufenkji, "Aggregation and deposition of engineered nanomaterials in aquatic environments: role of physicochemical interactions," Environmental Science and Technology, vol. 44, no. 17, pp. 6532-6549, 2010.

[10] G. V. Lowry, K. B. Gregory, S. C. Apte, and J. R. Lead, "Transformations of nanomaterials in the environment," Environmental Science and Technology, vol. 46, no. 13, pp. 6893-6899, 2012.

[11] H. Ma, P. L. Williams, and S. A. Diamond, "Ecotoxicity of manufactured $\mathrm{ZnO}$ nanoparticles-a review," Environmental Pollution, vol. 172, pp. 76-85, 2013.

[12] M. L. Fernández-Cruz, T. Lammel, M. Connolly et al., "Comparative cytotoxicity induced by bulk and nanoparticulated $\mathrm{ZnO}$ in the fish and human hepatoma cell lines PLHC-1 and Hep G2," Nanotoxicology, vol. 7, no. 5, pp. 935-952, 2013.

[13] S.-W. Bian, I. A. Mudunkotuwa, T. Rupasinghe, and V. H. Grassian, "Aggregation and dissolution of $4 \mathrm{~nm} \mathrm{ZnO}$ nanoparticles in aqueous environments: Influence of $\mathrm{pH}$, ionic strength, size, and adsorption of humic acid," Langmuir, vol. 27, no. 10, pp. 6059-6068, 2011.

[14] I. A. Mudunkotuwa, T. Rupasinghe, C.-M. Wu, and V. H. Grassian, "Dissolution of $\mathrm{ZnO}$ nanoparticles at circumneutral $\mathrm{pH}$ : a study of size effects in the presence and absence of citric acid," Langmuir, vol. 28, no. 1, pp. 396-403, 2012.

[15] R. Ma, C. Levard, F. M. Michel, G. E. Brown, and G. V. Lowry, "Sulfidation mechanism for zinc oxide nanoparticles and the 
effect of sulfidation on their solubility," Environmental Science and Technology, vol. 47, no. 6, pp. 2527-2534, 2013.

[16] J. Lv, S. Zhang, L. Luo et al., "Dissolution and microstructural transformation of $\mathrm{ZnO}$ nanoparticles under the influence of phosphate," Environmental Science and Technology, vol. 46, no. 13, pp. 7215-7221, 2012.

[17] R. D. Handy, R. Owen, and E. Valsami-Jones, "The ecotoxicology of nanoparticles and nanomaterials: current status, knowledge gaps, challenges, and future needs," Ecotoxicology, vol. 17, no. 5, pp. 315-325, 2008.

[18] A. Dhawan and V. Sharma, "Toxicity assessment of nanomaterials: methods and challenges," Analytical and Bioanalytical Chemistry, vol. 398, no. 2, pp. 589-605, 2010.

[19] Z. Pan, J. Tao, Y. Zhu, J.-F. Huang, and M. Parans Paranthaman, "Spontaneous growth of $\mathrm{ZnCO} 3$ nanowires on $\mathrm{ZnO}$ nanostructures in normal ambient environment: unstable $\mathrm{ZnO}$ nanostructures," Chemistry of Materials, vol. 22, no. 1, pp. 149-154, 2010.

[20] R. B. Reed, D. A. Ladner, C. P. Higgins, P. Westerhoff, and J. F. Ranville, "Solubility of nano-zinc oxide in environmentally and biologically important matrices," Environmental Toxicology and Chemistry, vol. 31, no. 1, pp. 93-99, 2012.

[21] Y. Sivry, A. Gelabert, L. Cordier et al., "Behavior and fate of industrial zinc oxide nanoparticles in a carbonate-rich river water," Chemosphere, vol. 95, pp. 519-526, 2014.

[22] M. M. Wang, Y. C. Wang, X. N. Wang et al., "Mutagenicity of $\mathrm{ZnO}$ nanoparticles in mammalian cells: role of physicochemical transformations under the aging process," Nanotoxicology, vol. 9, no. 8, pp. 972-982, 2015.

[23] H. Zhang, Q. Huang, A. Xu, and L. Wu, "Spectroscopic probe to contribution of physicochemical transformations in the toxicity of aged $\mathrm{ZnO}$ NPs to Chlorella vulgaris: new insight into the variation of toxicity of ZnO NPs under aging process," Nanotoxicology, vol. 10, no. 8, pp. 1177-1187, 2016.

[24] W. Song, J. Zhang, J. Guo et al., "Role of the dissolved zinc ion and reactive oxygen species in cytotoxicity of $\mathrm{ZnO}$ nanoparticles," Toxicology Letters, vol. 199, no. 3, pp. 389-397, 2010.

[25] A. Kumar, A. K. Pandey, S. S. Singh, R. Shanker, and A. Dhawan, "Engineered $\mathrm{ZnO}$ and $\mathrm{TiO} 2$ nanoparticles induce oxidative stress and DNA damage leading to reduced viability of Escherichia coli," Free Radical Biology and Medicine, vol. 51, no. 10, pp. 1872-1881, 2011.

[26] R. J. Vandebriel and W. H. De Jong, "A review of mammalian toxicity of $\mathrm{ZnO}$ nanoparticles," Nanotechnology, Science and Applications, vol. 5, no. 1, pp. 61-71, 2012.

[27] D. Fernández, C. García-Gómez, and M. Babín, "In vitro evaluation of cellular responses induced by $\mathrm{ZnO}$ nanoparticles, zinc ions and bulk $\mathrm{ZnO}$ in fish cells," Science of the Total Environment, vol. 452-453, pp. 262-274, 2013.

[28] Y. Song, R. Guan, F. Lyu, T. Kang, Y. Wu, and X. Chen, "In vitro cytotoxicity of silver nanoparticles and zinc oxide nanoparticles to human epithelial colorectal adenocarcinoma (Caco-2) cells," Mutation Research - Fundamental and Molecular Mechanisms of Mutagenesis, vol. 769, pp. 113-118, 2014.

[29] Preliminary Comments Review of the National Nanotechnology Initiative, National Research Council (US) Committee for the Review of the National Nanotechnology Initiative, National Academies Press, Wash, USA, 2001.

[30] R. Yoshida, D. Kitamura, and S. Maenosono, "Mutagenicity of water-soluble $\mathrm{ZnO}$ nanoparticles in Ames test," The Journal of Toxicological Sciences, vol. 34, no. 1, pp. 119-122, 2009.
[31] K.-S. Ko and I. C. Kong, "Toxic effects of nanoparticles on bioluminescence activity, seed germination, and gene mutation," Applied Microbiology and Biotechnology, vol. 98, no. 7, pp. 32953303, 2014

[32] Z. Emami-Karvani and P. Chehrazi, "Antibacterial activity of $\mathrm{ZnO}$ nanoparticle on gram-positive and gram-negative bacteria," African Journal of Microbiology Research, vol. 5, no. 12, pp. 1368-1373, 2011.

[33] M. Heinlaan, A. Ivask, I. Blinova, H.-C. Dubourguier, and A. Kahru, "Toxicity of nanosized and bulk $\mathrm{ZnO}, \mathrm{CuO}$ and $\mathrm{TiO}_{2}$ to bacteria vibrio fischeri and crustaceans daphnia magna and thamnocephalus platyurus," Chemosphere, vol. 71, no. 7, pp. 1308-1316, 2008.

[34] K. R. Raghupathi, R. T. Koodali, and A. C. Manna, "Sizedependent bacterial growth inhibition and mechanism of antibacterial activity of zinc oxide nanoparticles," Langmuir, vol. 27, no. 7, pp. 4020-4028, 2011.

[35] R. Ma, C. Levard, J. D. Judy et al., "Fate of zinc oxide and silver nanoparticles in a pilot wastewater treatment plant and in processed biosolids," Environmental Science and Technology, vol. 48, no. 1, pp. 104-112, 2014.

[36] H. Zhou, X. Wang, Y. Zhou, H. Yao, and F. Ahmad, "Evaluation of the toxicity of $\mathrm{ZnO}$ nanoparticles to Chlorella vulgaris by use of the chiral perturbation approach Euroanalysis XVII," Analytical and Bioanalytical Chemistry, vol. 406, no. 15, pp. 3689-3695, 2014.

[37] A. M. Ueno, D. B. Vannais, D. L. Gustafson, J. C. Wong, and C. A. Waldren, "A low, adaptive dose of gamma-rays reduced the number and altered the spectrum of S1- mutants in humanhamster hybrid A(L) cells," Mutation Research-Fundamental and Molecular Mechanisms of Mutagenesis, vol. 358, no. 2, pp. 161-169, 1996.

[38] T. K. Hei, S. U. X. Liu, and C. Waldren, "Mutagenicity of arsenic in mammalian cells: role of reactive oxygen species," Proceedings of the National Academy of Sciences of the United States of America, vol. 95, no. 14, pp. 8103-8107, 1998.

[39] S. George, S. Pokhrel, T. Xia et al., "Use of a rapid cytotoxicity screening approach to engineer a safer zinc oxide nanoparticle through iron doping," ACS Nano, vol. 4, no. 1, pp. 15-29, 2010.

[40] L. Bao, A. Xu, L. Tong et al., "Activated toxicity of diesel particulate extract by ultraviolet a radiation in mammalian cells: role of singlet oxygen," Environmental Health Perspectives, vol. 117, no. 3, pp. 436-441, 2009.

[41] A. E. Nel, L. Mädler, D. Velegol et al., "Understanding biophysicochemical interactions at the nano-bio interface," Nature Materials, vol. 8, no. 7, pp. 543-557, 2009.

[42] R. Ma, C. Levard, S. M. Marinakos et al., "Size-controlled dissolution of organic-coated silver nanoparticles," Environmental Science and Technology, vol. 46, no. 2, pp. 752-759, 2012.

[43] B. C. Reinsch, C. Levard, Z. Li et al., "Sulfidation of silver nanoparticles decreases Escherichia coli growth inhibition," Environmental Science and Technology, vol. 46, no. 13, pp. 69927000, 2012.

[44] D. Li, D. Y. Lyon, Q. Li, and P. J. J. Alvarez, "Effect of soil sorption and aquatic natural organic matter on the antibacterial activity of a fullerene water suspension," Environmental Toxicology and Chemistry, vol. 27, no. 9, pp. 1888-1894, 2008.

[45] S. Mahendra, H. Zhu, V. L. Colvin, and P. J. Alvarez, "Quantum dot weathering results in microbial toxicity," Environmental Science and Technology, vol. 42, no. 24, pp. 9424-9430, 2008. 
[46] K. Dixon and E. Kopras, "Genetic alterations and DNA repair in human carcinogenesis," Seminars in Cancer Biology, vol. 14, no. 6, pp. 441-448, 2004.

[47] N. M. Franklin, N. J. Rogers, S. C. Apte, G. E. Batley, G. E. Gadd, and P. S. Casey, "Comparative toxicity of nanoparticulate $\mathrm{ZnO}$, bulk $\mathrm{ZnO}$, and $\mathrm{ZnCl}_{2}$ to a freshwater microalga (Pseudokirchneriella subcapitata): the importance of particle solubility," Environmental Science \& Technology, vol. 41, no. 24, pp. 8484-8490, 2007.

[48] M. Li, D. Lin, and L. Zhu, "Effects of water chemistry on the dissolution of $\mathrm{ZnO}$ nanoparticles and their toxicity to Escherichia coli," Environmental Pollution, vol. 173, pp. 97-102, 2013.

[49] X. Zhu, L. Zhu, Z. Duan, R. Qi, Y. Li, and Y. Lang, "Comparative toxicity of several metal oxide nanoparticle aqueous suspensions to Zebrafish (Danio rerio) early developmental stage," Journal of Environmental Science and Health-Part A Toxic/ Hazardous Substances and Environmental Engineering, vol. 43, no. 3, pp. 278-284, 2008. 

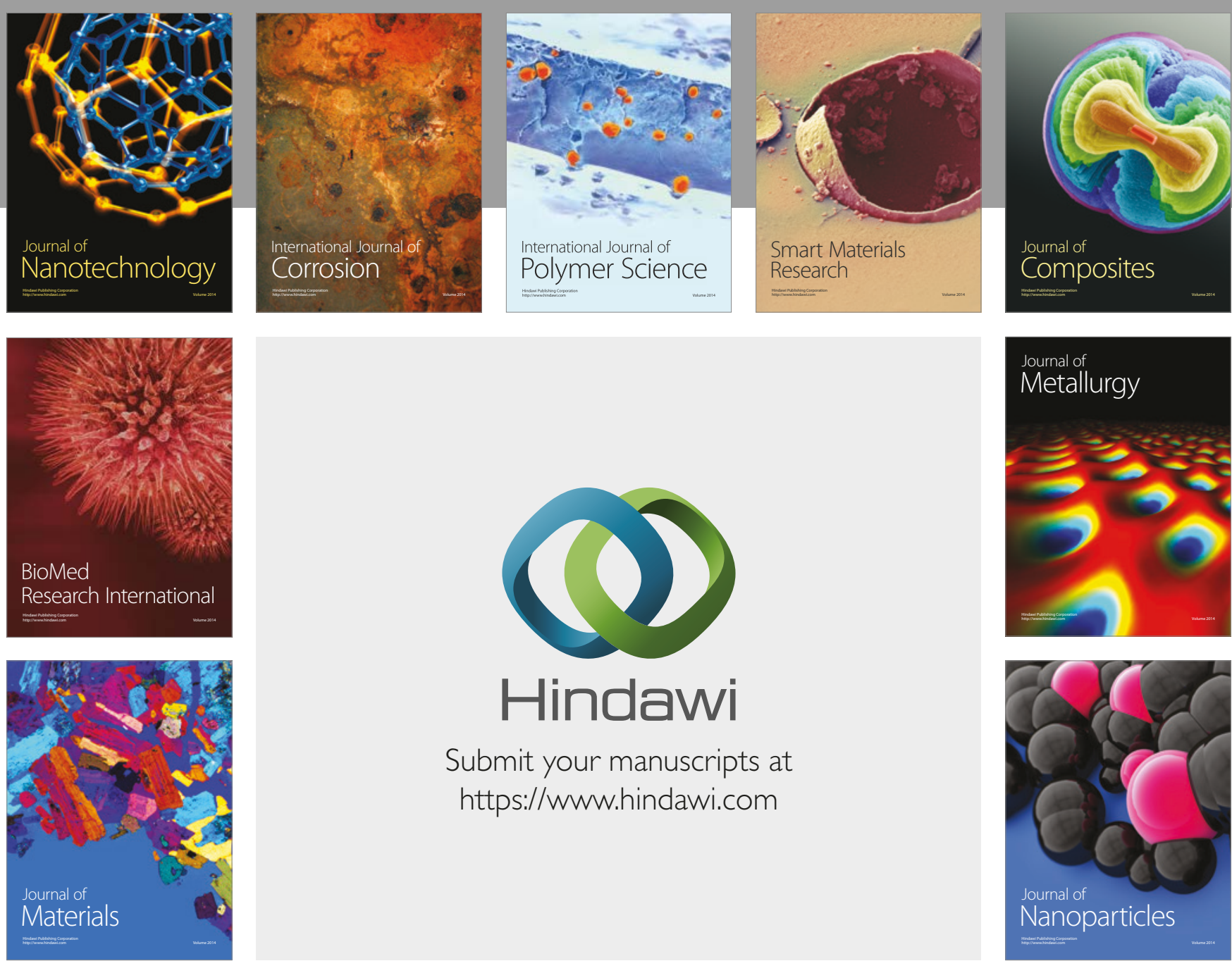

\section{Hindawi}

Submit your manuscripts at

https://www.hindawi.com
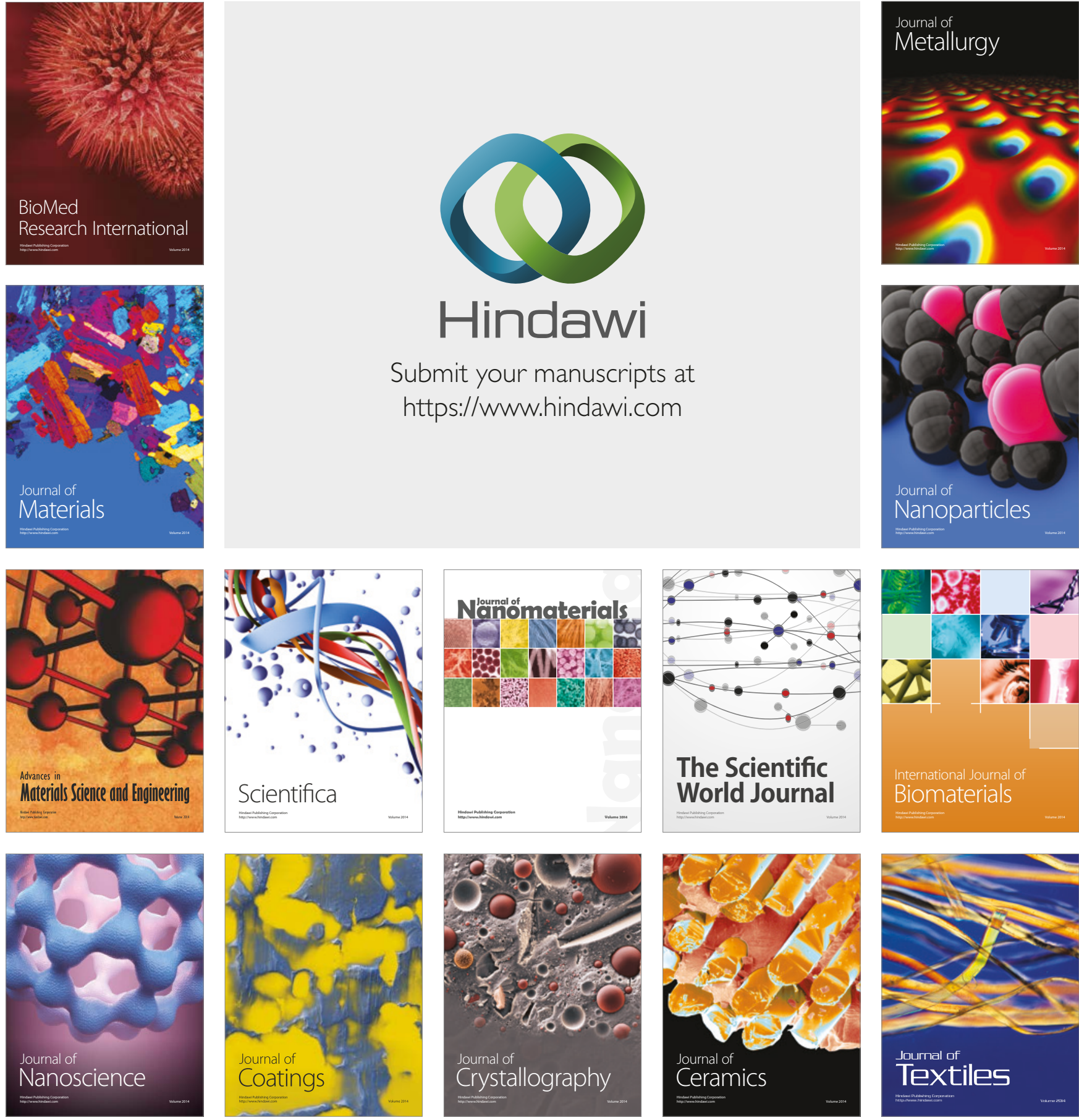

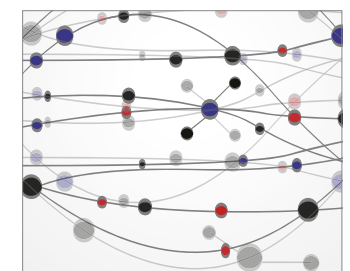

The Scientific World Journal
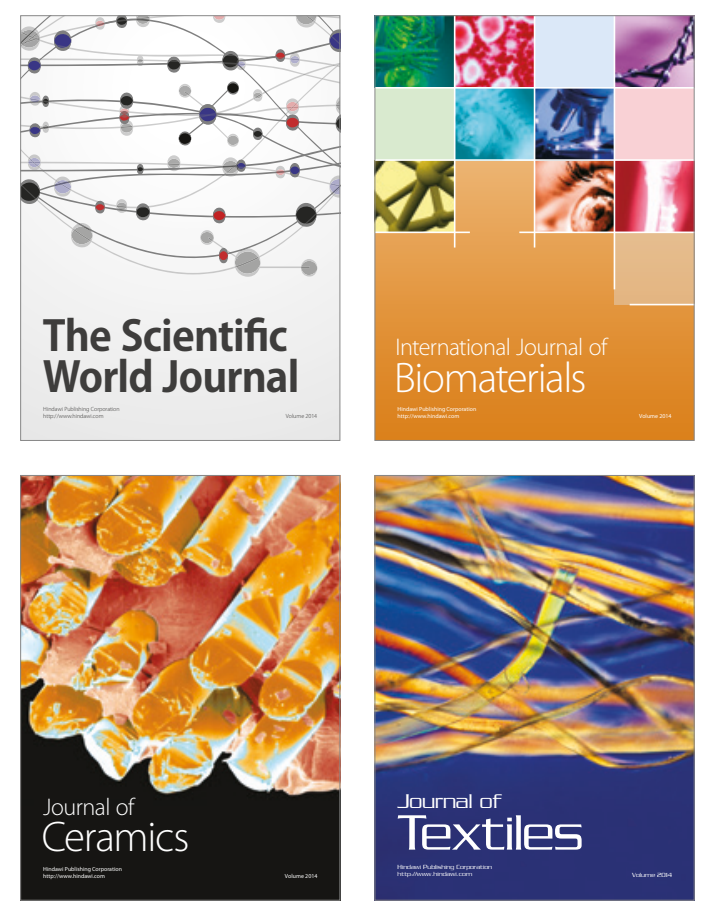